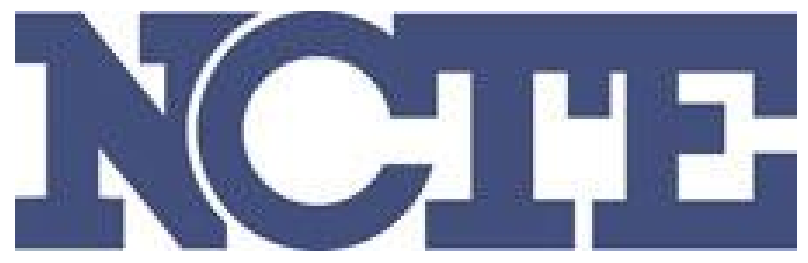

\title{
Reality, Consensus, and Reform in the Rhetoric of Composition Teaching
} Author(s): Greg Myers

Source: College English, Vol. 48, No. 2 (Feb., 1986), pp. 154-174

Published by: National Council of Teachers of English

Stable URL: http://www.jstor.org/stable/377298

Accessed: 09-08-2016 16:42 UTC

Your use of the JSTOR archive indicates your acceptance of the Terms \& Conditions of Use, available at

http://about.jstor.org/terms

JSTOR is a not-for-profit service that helps scholars, researchers, and students discover, use, and build upon a wide range of content in a trusted digital archive. We use information technology and tools to increase productivity and facilitate new forms of scholarship. For more information about JSTOR, please contact support@jstor.org.

National Council of Teachers of English is collaborating with JSTOR to digitize, preserve and extend access to College English 


\section{Reality, Consensus, and Reform in the Rhetoric of Composition Teaching}

I would like to raise some political questions about two methods of teaching I use in my writing classes: having small groups of students collaborate on and critique each others' writing, and having case assignments based on some actual writing situation, whether a technical proposal or an anthropology exam. My thinking about these methods is based largely on the detailed and practical suggestions of Peter Elbow and Kenneth Bruffee, and on discussion of their works with other teachers. My means of raising questions will be to compare the writings of Elbow and Bruffee to the work of an earlier writer, Sterling Andrus Leonard (1888-1931), whose Dewey-inspired English education textbook, English Composition as a Social Problem, suggested these two teaching methods, which I had considered new, back in 1917. I revive this now-forgotten writer and make these comparisons for two reasons: 1) the distance in time makes it easier for us to see his social context than it is to see the context of Elbow or Bruffee, and 2) the recurrence of these ideas as new ideas suggests that those of us who want to change the way writing is taught tend to overlook the efforts and the lessons of earlier reformers. As Lawrence Cremin says in his history of the progressive movement in education, of which Leonard was a part, "Reform movements are notoriously ahistorical in outlook" (8). Until recently, this ahistoricism has been characteristic of composition theory, with its reformist attacks on a monolithic tradition. ${ }^{1}$

Leonard's writings are interesting in themselves, even considered apart from their historical importance, and deserve to be rescued from the storage rooms of teachers' college libraries. Besides the comments on collaborative learning and "real" writing that I will be considering, he made a number of other criticisms and suggestions between 1914 and 1930 that could be taken from this year's issues of College Composition and Communication or College English:

1. Some recent historical studies that discuss reform in composition include those by James Berlin (whose book has an extensive bibliography), Michael Halloran, Robert Conners, Wallace Douglas, (whose article appears in a special issue of the English Journal devoted to the history of the profession), and Evelyn Wright.

Greg Myers is now teaching at the University of Lancaster, England, and is writing a book about the social construction of scientific texts. He wrote this article while teaching in the rhetoric program at The University of Texas at Austin.

College English, Volume 48, Number 2, February 1986 
On the composing process: "The ideal of the finished product is absolutely vicious, except as it functions to determine the remote goal.' (English Composition 190)

On the development of writing abilities: "Indeed, growth in the art of writing or speaking may be defined simply as a process of becoming increasingly reader-minded." (English Composition 14)

On freewriting: "Some may really do best to write first in mad and scrabble haste, for themselves only, and thus clear their thoughts before they attempt to talk or write for anyone else." (English Composition 111)

On the modes: "Useful as this [classification of the forms of discourse] doubtless is for sorting completed pieces of writing, it does not view the process of writing from the side of the thoughts or ideas the writer has to express and particularly of his purpose in expressing those." ("As to the Forms of Discourse" 202)

He also makes suggestions on invention, on sentence combining, on Piaget's theories, and on the need to avoid petty criticisms of errors and unrealistic, "schoolmastering" standards of usage. ${ }^{2}$ But what most interests me is his answer to what he calls "the central problem" of his English education work:

How, stirred by . . . interesting problems requiring expressing, can the school class be knit into a social group organized for mutual help, and aided to move steadily forward in the arduous way of attaining effective expression? (35).

His emphases on the class as a social group, and on the real basis of writing in "interesting problems" of the students' communities inside and outside the school, anticipate the current interest in what Patricia Bizzell calls "social processes whereby language learning and thinking capacities are shaped and used in particular communities" (215). I will try to show that he also anticipates some of the political dilemmas of present-day reformers.

\section{Some Terms: Ideology, Consensus, and Reality}

I will be criticizing two sorts of rhetorical appeals that Leonard, and later Elbow and Bruffee, use in arguing for the teaching of writing through groups: an appeal to the authority of consensus, and an appeal to the authority of reality. It may seem perverse to object to appeals that are so common in our field and that are apparently progressive: surely we all see the need to come to reasoned agreement within a community, and to relate our teaching to the real world. To explain why I find these appeals problematic, I need to draw on an indispensible piece of Marxist jargon, the concept of ideology. I am not using the word the way it is commonly used to criticize any systematic political belief, as, say, an

2. See English Composition as a Social Problem for references to invention (81), sentence-combining (158), "schoolmastering"' (183 and many other references). On Piaget, see "Relating the Teaching of English to Reality"'(45). 
unsympathetic reader of this article might say my views were distorted by Left wing ideology. I am using it in the sense established by Marx, and modified by twentieth-century Marxists, to describe the whole system of thought and belief that goes with a social and economic system, the thoughts that structure our thinking so deeply that we take them for granted, as the nature of the real world. The concept has been much discussed by Marxists because it helps explain the apparent stability of the capitalist system, despite all its contradictions. It helps explain why people who are oppressed seem to go along with their oppression; the ideology of the oppressive system gives them the structures through which they make sense of their world. ${ }^{3}$

The concept of ideology has been of particular interest to Marxist sociologists of education, who see the school as, at least in part, an institution that adapts ideology to changing economic and social conditions, and produces a new version of ideology for each generation. Schools not only teach academic knowledge; they teach work according to schedule, acceptance of authority, and competition among individuals and between groups. They also help provide a justification for the hierarchies of society, so that, for instance, people accept that manual labor should pay less than mental labor. This process of adapting and carrying on the assumptions of our society is called reproducing ideology, by analogy with Marx's description of the reproduction of capital. Recently, radical teachers have asked if school can also be a place where people can resist the reproduction of ideology; they have put less emphasis on the all-embracing power of ideology as a structure, and have focused on the ways students and teachers can break this unthinking acceptance of ideas that support the way things are.$^{4}$ Of course, many teachers who are not Marxists agree that the vast differences in our society between rich and poor, black and white, men and women, are bad, and many teachers agree that critical thinking is a good thing. Where Marxist teachers differ from other critics of these injustices is in arguing that the social and economic system that perpetuates the injustices builds a protective structure of ideology that prevents us from thinking critically about it. Thus, what we might think is free and progressive thought may be another way of perpetuating a system we want to change.

I will argue that ideas of consensus and reality, as they are used by Leonard, though they seem so progressive, are part of the structure of ideology. The construction of a sense of general agreement is as important to the rhetoric of composition teaching as it is to the rhetoric of national politics; look, for instance, at all the articles in this journal asserting a new paradigm in the profession. But if conflict is part of the system, and is necessary to change the system, then consensus, within the system as it is, must mean that some interests have been suppressed or excluded. Similarly, it is common in our profession to show oneself

3. For a discussion of the term, see Raymond Williams, Keywords. For a series of reviews of various studies of ideology, see Centre for Contemporary Cultural Studies, On Ideology.

4. Several detailed historical and sociological studies along these lines are collected in Michael Apple, ed., Cultural and Economic Reproduction in Education. Important earlier articles on ideology in education are collected in the Open University reader, Roger Dale et al., eds., Schooling and Capitalism: A Sociological Reader. A recent analysis of educational theories, in clear but rather abstract terms, is Henry Giroux, Theory and Resistance in Education: A Pedagogy for the Opposition. Current critical articles on the sociology of education often appear in the journal Curriculum Inquiry. 
as escaping tired academic forms to enter the real world. But if what we take as reality is always a social construction, then to accept the reality we see now is to accept the structure of illusion our system gives us. Worse, it is to see reality as something natural, outside our control, rather than to see it as something we make in our actions in society.

Since many readers who see the same economic, racial, and sexist injustices I do may not share my conviction that the problems are fundamental and systematic, it may help to use a familiar example from a society all readers will believe is fundamentally and systematically unjust. Huckleberry Finn's thinking is structured by the ideology of a slave-holding society. Though Huck himself does not own any slaves or benefit from this society (recall that he has invested some capital that he found), he hates abolitionists, and he can only think about blacks and whites in the terms he has learned. (Every reader must recall the exchange he has when he tells Aunt Sally the steamboat had blown a cylinder head: "Good gracious! Anybody hurt?-No'm. Killed a nigger.-Well, it's lucky; because sometimes people do get hurt.') But for reasons Huck doesn't entirely understand, and which he would not consider as being in any way political, he is capable of some remarkable acts of resistance to this system: for instance, he makes up elaborate lies on the spur of the moment to keep slave hunters away. There is some chance for change as long as he and others are capable of such resistance. But still he consciously believes in the institution of slavery enough so that he thinks worse of Tom Sawyer, a good boy, for apparently helping free Jim. Huck himself is an agreeable sort who prefers to avoid trouble. Whenever he tries to approach the consensus view, to do what he believes is right, he thinks of returning his friend Jim to slavery. Towards the end of the book, he believes he is finally facing reality when he admits to himself that in helping Jim escape, he is guilty of stealing property from Jim's owner. Now I am not saying that the social system of present day New York or Texas or Lancashire, where I have been teaching, is like that of ante-bellum Missouri where Huck grows up; what I am saying is that our social system constructs our view of the world as slavery does Huck's, and that the appeals to consensus and to reality may support that ideological view, as they did for Huck.

\section{Sterling Leonard and Consensus}

I have commented on how current Sterling Leonard's ideas sound today. I would argue that this is because the historical conditions of high school English education in his period, 1900-1930, have some similarities to those in college, and particularly community college, English education in our own time. The high schools then were adapting to a massive influx of immigrants, and to the enrollment of working class students who had previously left school early, if they had attended at all..$^{5}$ In a similar way, writing programs like those at the City University of New York have faced the institutional challenge of coping with a group of students who would not previously have attended a university. In both

5. See Cremin; David Hogan, "Education and Class Formation: The Peculiarities of Americans," in Apple's collection; and Diane Ravitch's quite readable book on the case of New York City. 
periods, the new students changed the institutions, as well as being changed by them. In both periods, the institutions were responding to the demands of business for a large workforce with a different kind of skills. And in both periods, the teachers of writing were trying to establish their own professional status. A sense of historical conditions can help us see Leonard's progressivism in a social context.

Leonard was a typical reformer of this period, and one could find ideas similar to his in the work of John Dewey, E. L. Thorndike, George Philip Krapp, Fred Newton Scott, C. C. Fries, and I. A. Richards. ${ }^{6}$ Leonard worked with all these teachers, in his own schooling at Michigan and Columbia Teachers' College or in his later work as a professor at Wisconsin and a leader of the then new NCTE. But the most important influence on him, and an important influence still on composition theory, was the work of John Dewey. It was from Dewey that Leonard took his central theme-and the theme of most importance to us in trying to criticize his work-the idea of the school as an image of society. For instance, in The School and Society (1898), Dewey says, "The great thing to keep in mind, then, regarding the introduction into the school of various forms of active occupation, is that through them the entire spirit of the school is renewed ... It gets a chance to become a miniature community, an embryonic society" (15). This quotation refers to both the elements I want to discuss in Leonard's work, the use of the social group of the class, and the emphasis on "real projects," with their reality defined by the analogy to the world outside the school.

Leonard's emphasis on the class as a social group is not just dogmatic Deweyism; he has clearly taught and learned from classes taught this way. In English Composition as a Social Problem, for example, he anticipates current ideas in using group work as the basis for "prevision of ideas" (invention), for revision suggestions, and for setting standards of usage. He has practical suggestions to make on teachers' direction of class experimentation (22), on responding (or not responding) to spoken errors (42), on introducing the class to criticism of students' writing (47), on letting the class make up terminology (77), on withholding one's criticisms (97), and on restraining students' carping criticisms of each other: "We must encourage prompt condemnation of guerilla pettifogging whenever we discover signs of it" (164). These passages remind the reader today of the practical advice in Bruffee's A Short Course in Writing or Elbow's Writing Without Teachers.

But there are passages in which Leonard describes the authority of the classroom group that should make us aware of the dangers of a consensus-based method. Leonard sees his method as furthering the sort of democracy in education promised by Dewey, a democracy he does not see in the traditional classroom. "Our present classrooms are designed chiefly for securing a maximum of

6. Biographical information on Leonard is from W. E. Leonard's $D A B$ entry. Background to the period is from the books by J. N. Hook and Arthur Applebee, and from Merle Curti's contemporary study. Curti, like me, looks at these ideas from the left, but he considers Dewey's influence entirely progressive. A reviewer of my article recommended the chapter on Leonard by John Brereton in Traditions of Inquiry (New York: Oxford UP, 1985). The whole book should be relevant to my topic here, but it was unavailable in Britain as I revised this article. 
order and dispatch. Parliamentary practice is demanded in the custom of addressing the teacher always, and is parodied in the raising of right hands for recognition"' (40). Leonard's students have much more to do with each other than this; they are "an interested group of cooperative workers" (65). The danger is that the teacher has merely embodied his or her authority in the more effective guise of class consensus. This guided consensus has a power over individual students that a teacher can not have alone. "What the class may be able, with the help and suggestion of their leader, truly to realize as quite undesirable-cheap or smart or the like-may be quietly branded by the common judgment as unacceptable, and really eliminated" (130). Any teacher who uses group discussions or projects has seen that they can, on occasion, be fierce enforcers of conformity. And Leonard welcomes this enforcement with less worry than we might have. "The erring will be helped sufficiently by a sensation of lowered class temperature, so sharp that even the least sensitive cannot escape it" (149). Leonard does not himself use, but refers to, another teacher's "device ... of having all children look for such violations [of rules of usage] by any member of the group anywhere and report complete statements and names, and then of deputing committees to write out all such reports on the blackboard each week" (150). Such elaborate machinery might occur to a teacher only during a period of war-time red-baiting hysteria (this was written in 1917), but the tendency to unthinking conformity is always there when consensus is used to set and enforce standards.

The emphasis on the authority of the group that we see in Leonard's textbook is apparent also in his most influential research, his usage studies that attempt to show the differences between formal textbook prescriptions and the language actually used in social transactions. For him the choice is not between correct and incorrect forms, but between the real world of actual usage and the unreal world of school English: "The question appears to turn on whether we wish in these grade and high school years to cultivate excellent homely expressions to fit the daily, informal occasions that we all have to meet most often, or rather a bookish and formal type exclusively"' (132). Here he attacks something like what Ken Macrorie calls "Engfish." Leonard does believe that there are some arbitrary rules that must be taught as arbitrary rules. But he believes these rules are very few; thus he is interested in the definition of what the NCTE then called "Minimum Essentials," making a short list of items to be taught by all teachers and consigning the rest of the handbook items to oblivion.

Leonard's authority for the selection of these "essential" items would be actual usage; he has nothing but scorn for the John Simons and Edwin Newmans of his day who would try to impose puristic usage by fiat. "It is easy," he wrote in an early article, "to compile and propagate handbooks of baseless prescriptions; and people will buy them, just as they will buy manuals of etiquette, simply because these announce so many things which 'aren't done' that everyone is convicted of a sin and hastens to remedy the evil. But neither language nor other phases of good manners are settled by these means" ("What About Correct English?', 255). In his Columbia dissertation, The Doctrine of Correctness in English Usage, 1700-1800, he traces the origins of many of the handbook rules, and shows they have no basis in the actual usage of any period. This study led to 
Current English Usage, a massive survey to show how little "cultivated usage" supports the handbooks on most disputed items. ${ }^{7}$ His views, progressive for the time, had a strong influence on the NCTE's position on usage. But we should note that Leonard's constant appeal to consensus usage assumes the inherent superiority of certain language groups. When he compares grammar books to etiquette books, he assumes, correctly I think, that issues of grammar are debated with such heat because they conceal issues of class, and especially the uneasiness of the middle class about its status. But there is little sense in his usage studies that there might not be just one answer for each item, that different classes or regions or races might have different usages, and that conflicts between these usages reflect other social conflicts. Instead, he carefully chooses certain kinds of respondents, and carefully figures the percentages of respondents approving of each item, and takes the majority vote as the right answer. His authority, he says, is "what various judges have observed about actual use or non-use by cultivated persons" ("Current Definition of Levels in English Usage" 345). But note it is cultivated persons who are to be considered, and experts who are to be the judges. The notion of consensus in usage, while it seems democratic, ignores the conflicts that characterize language change, and leaves the authority of certain types of language unquestioned.

It may seem odd to insist that large social conflicts are behind the use of groups to critique students' papers or the decision on when to use the subjunctive. But Leonard's exercises in democracy can be seen as part of a larger effort to create consensus by eliminating or at least concealing diversity and conflict. This diversity is so well concealed that anyone reading Leonard's articles now, or reading any sampling of articles from the NCTE's English Journal of his period, could remain unaware that teachers in many cities would be teaching classes in which most students were foreign born. ${ }^{8}$ The only indication of potential conflict would be the way that progressive and traditional educators alike made every class into a civics lesson. If one believes that the society of that time was basically just, and that the treatment of the immigrants and workers, and their children, was just, then the attempt to integrate these newcomers into a consensus view, into the melting pot, was a generous project. But if one reads the history of that period as a history of challenges to a system that promoted great extremes of poverty and wealth, and terrible conditions of living and work, challenges by labor unions, immigrant communities, and new black urban communities, then the attempt by educators to deny the existence of these challenges can be seen as part of a repressive response by the government and corporations. Leonard's Deweyan individualism, though it still sounds progressive to us, strips the student of any identification with class, religion, family, or origins. And these identifications, as we are now coming to see in the controversies over bi-cultural education, can be the beginnings of political action. Deweyan education reassembles these students as units in a classroom group, in which

7. Leonard's study, which he left incomplete at his death, is included in Albert Marckwardt's Facts About Current English Usage.

8. On Americanization, see Cremin; Hook; Ravitch; and English Journal in the 1920s. 
they are conscious only of the demands of a monolithic "society" as enforced by the school and by other students.

\section{Leonard and Reality}

It may seem paradoxical, or even perverse, for a radical who keeps referring to the social and economic basis of education to criticize the emphasis on reality in the work of Leonard and other progressive educators. Aren't they trying to do, in a practical way, just what I insist on doing in theory? The difference in our views is in how we define reality. For Leonard, what is real is given; we gain knowledge of it through our senses, if we are not deceived by non-empirical assumptions, and we adapt to it as best we can. For a Marxist, reality is not a monolithic thing out there, but a process in society, an ongoing conflict between various groups, which in turn structures that society. People have no simple unmediated perception of reality; the facts we are likely to take as reality are most likely parts of another ideological structure. Think, for example, of the very limited sense "the real world" has had in recent discussion of writing courses-it becomes synonymous with the demands of employers as shown in surveys. By treating the "real world" as the bedrock of our teaching, we perpetuate the idea that reality is something outside us and beyond our efforts to change it.

We have seen that Leonard's rhetorical strategy in his attacks on what he calls "Old Purist Junk" about usage is to compare the formalism of textbooks with the way people use language in the "real world." He makes a similar appeal in replacing the teaching of the modes of discourse with a developmental classification based on the stages a child is supposed to go through in learning the presentation and interpretation of facts. In the earliest assignments a student receives, the student simply reports observations: "All these matters are to be presented as objectively as possible; they are to set forth all the writer's senses have apprehended" ("As to the Forms of Discourse" 202). The purpose of this exercise is to root out merely conventional beliefs, by making the students stick to the facts: "Nothing is of more doubtful value, as an exercise in composition or anything else, than the restatement of fact or interpretation the writer has absorbed but not lived or thought through himself" ("As to the Forms of Discourse" 204). Now I have been attacking just this handing on of uncriticized assumptions. But I disagree with Leonard's belief that the facts lie outside these assumptions. If what we think of as facts are determined by our ideological framework, the facts cannot themselves get us beyond that framework. ${ }^{9}$ Leonard's textbook says, as do many textbooks today, "The whole art of helping children in writing or speaking, as this study urges it, is based on the idea of showing them how to search out and give not general but specific details" (English Composition 105). I too am always asking students for more details. But I am interested in what such details reveal about our assumptions, not in getting beyond assumptions to some external reality.

9. See Richard Ohmann, "Use Specific, Definite, Concrete Language." 
To take an example, Leonard asks his students to describe a place, and to cut out any statements unsupported by facts. That may lead to a more readable and more academic sounding paper, but it will not tell us what the place is really like. When, for instance, the various students in a basic writing course at Queens College write comparisons of the places they live to the places their parents lived as children, what these places are "really like" is determined by conventional frameworks of progress or nostalgia. What the place is really like might be better understood by comparing all those unsupported generalizations that various people would bring to such a description, comparing, say, the Lower East Side described as oppressive ghetto with the Lower East Side described as warm community, Forest Hills described as success and security with Forest Hills described as silent streets and alienating apartment blocks. No careful attention to the description of stoops or wide lawns will reconcile these descriptions in one objective reality. Both express deeper tensions that go beyond the rhetorical problems set by the assignment.

There is at times an alarming sound to Leonard's enthusiasm for the real world, as there is to his enthusiasm for consensus, that should make us examine our own enthusiasms today. His demand that development in school lead to the world of work and community responsibility, while it frees the school from the empty formalism of lectures, drills, and theme topics, ironically makes it more subservient to ideology. The real world is indistinguishable from the world defined by business publicists: "Meat packers, electric companies, millers, dog breeders, and others have free advertising matter and exhibits which are of the greatest value. Whatever your children want to know is likely to be covered by government or advertising material" ("Composition and Grammar in the Junior High School" 410). Despite the apparent naiveté of this view, Leonard is not by any means a promoter of a narrowly vocational education. Dewey had described the relation between business and education in broad terms.

Though there should be an organic connection between the school and business life, it is not meant that the school is to prepare the student for any particular business, but that there should be a natural connection of the everyday life of a child with the business environment around him, and that it is the affair of the school to clarify and liberalize this connection, to bring it to consciousness, not by introducing special studies, like commercial geography and arithmetic, but by keeping alive the ordinary bonds of relation. (68)

It is not the connection of business that is in itself disturbing, but the sense of the naturalness and inevitability of this connection as the one way of reaching out to the world outside the school. For Leonard, as for Dewey, to criticize the subordination of education to the needs of business and government is to fail to face reality.

Teachers today are likely to be more skeptical about the uses of advertising. But we still assume the value of making the classroom represent "reality," and we still define this reality in very limited terms which we take uncritically from 
our economic system. For instance, many of the research studies that seek to define a body of good writing compare the writing of students to that of published writers. Now this makes for some valuable comparisons, but we should note how we just assume, lacking an agreed standard of writing quality, that good writing is writing that can be sold for money. Some editors of composition readers argue, using rhetoric very similar to Leonard's, that this sort of contemporary professional writing is more real than, say, readings taken from the canon of English and American literature. Or other editors of readers argue that the writing of students who have won a national essay contest is more real than the writing of professional magazine writers. All these assertions, whatever the pedagogical value of the materials they propose, beg the question of just how we come to define a real world, and accept that world as something given.

\section{Leonard and Reform}

Anyone who has sat through a dull writing class (or has oneself taught a dull class with growing frustration) would recognize Leonard's descriptions of traditional methods of teaching English. He attacks these classes using a rhetoric similar to that of composition reformers today, who present themselves as fighting for more realistic views against the tradition that prevailed before the mid-1960s. ${ }^{10}$ Much as I sympathize with the critique given by both periods of reform, I have questions about the way these reformers define themselves against the dubious practices of traditional teachers, who are often at a lower level of the hierarchy of educational prestige. The attack on tradition shifts our focus from the conflicting goals of the school in society to the simpler issue of the competence of individual teachers and the practicality of specific methods.

These questions may be raised most clearly by considering one of Leonard's articles from 1923. "How English Teachers Correct Papers" reports a study in which various groups of student-teachers and teachers were given a list of sentences from both students and famous authors and asked to mark any errors they would require a student to correct (517). Leonard's whole study is something of a trap for the unsuspecting teachers, practically all of whom "fatigued themselves to a point close to insensibility by meticulous correction of a great number of idioms in sentences by De Quincey, Lamb, Pater, Symonds, and authors of similar standing" (517), so that they were too tired to see what Leonard considered actual errors. To complete his attack, Leonard lists "constructive comments" the teachers gave on whole papers they were asked to mark, including "corrections" that made the correct incorrect, "puristic or wholly captious excisions, restatements, arrangements, and additions," and foolish or irrelevant criticisms. Leonard's suggestion that "the wisest teacher proceeds always by way of queries and suggestion, not by dogmatic rules and requirements," is a good one, and has been reiterated recently in articles in the composition journals

10. For an example of the rhetoric of composition reform, see Donald Stewart, "Composition Textbooks and the Assault on Tradition," and some of the other articles collected in Gary Tate and Edward P. J. Corbett, eds., The Writing Teacher's Sourcebook. 
reporting studies similar to Leonard's. ${ }^{11}$ But Leonard's article, like some recent critiques, presents a polemic against dogmatism without either an understanding of its origins, or a model for a new method based on queries and suggestion.

The study shows how much Leonard needs bad teachers to make his argument. I would not deny that there was, and is, a plentiful supply of such teachers to provide examples of arbitrary traditionalism. But I am uneasy with the way the university expert makes them the enemy. He shows how their habits fly in the face of the "reality" revealed by current research, and he judges their judgment against an absolute level of cultivation represented by the writing of "De Quincey, Lamb, Pater, Symonds, and authors of similar standing." I would argue that this kind of top-down reform leads nowhere, because it just reinforces the hierarchy of the teaching profession, reminding teachers that the expertise is somewhere else. Thus in each generation it is the reformers who chair committees, write articles, and edit the journals; by these standards it is the reformers who are the establishment, and the opponents they label traditionalists are the outsiders. And in the 1980s we use the same sort of rhetoric, on the same sort of issues, to the same sort of teachers, to distinguish ourselves from tradition, that the members of that "tradition" used against a previous generation. What is needed to break this circle is more understanding of the conditions under which people teach, and the ideological frameworks within which they think. We should be opposing, not traditional teachers, but a system in which such repressive teaching is, in fact, perfectly appropriate.

I am annoyed with Leonard's rhetoric as a reformer because he assumes authority over other teachers and over students while denying he has it. He assumes authority as trained expert, university professor, empirical researcher, voice of the downtrodden students, bringing enlightenment to normal-schooltrained teachers. But he denies his personal authority by saying the students are controlling the classroom, and his curriculum just follows the real world, and his reforms are based on the latest research. If we see that schools can be both places of liberation and places of oppression, then we have to ask how we are using what limited power over people's lives we do have.

\section{Consensus and Reality in Elbow and Bruffee}

If Leonard were just a forgotten hero of composition theory, like Alexander Bain or Fred Newton Scott, to revive him and then criticize him would be unnecessary and rather unfair. But the example of Leonard can help us criticize the presentation of consensus, reality, and reform in two theorists who carry on the tradition of progressive education, Peter Elbow and Ken Bruffee.

Elbow's Writing Without Teachers first introduced many of us to the usefulness of groups in the teaching of writing, and gave us some insights into their dynamics. But his more recent book, Writing With Power, shifts the emphasis

11. Leonard's study is similar to that in Nancy Sommer's recent article, "Responding to Student Writing." Like Leonard, Sommers only gives examples of comments that are badly done. Dan Moshenberg pointed out to me the similarity of Leonard's study to the experiment in poetry criticism I. A. Richards reports in Practical Criticism. 
away from the social context, returning to some essential internal power as a way of control of self and others. For Elbow, language may get work done in the social world, and the individual learner may use that social world as a tool to help him or her learn writing, but the system of language is produced by individuals, not by society. It is true that he seems to emphasize the social context of writing and the uses of consensus in his chapters on "Audience" and "Feedback." And he emphasizes the need to make the classroom reflect the world, using terms very much like those of Leonard: "any 'back to basics' movement in the teaching of writing needs to start by ensuring each child the most basic thing of all: a real audience for his written words-an audience that really listens and takes the interchange seriously" (184). This might seem to be a difficult need to satisfy in the composition class, but even in the artificial world of the classroom, "there is always a useful real audience available to whom writing can easily be delivered: other members of the class" (230).

For Elbow, as for Leonard, power over real audiences comes from an immediate connection with reality gained through a breaking down of stifling conventions. Writing with power requires authenticity of expression ("voice") and unmediated realism of perception in which the writer and reader must "see" the object written about (316). The problem with this call for direct experience of reality is that, as with Leonard, one must ask to which reality is one admitted. Elbow, unlike Leonard, acknowledges the existence of fundamentally different views of the world. But he still sees these views as free and individual, not acknowledging the way they are structured by ideology. So in his book, reality is divided between a cold, clear outside and a warm, messy inside. Writing consists of the negotiation between these two sides of the individual. In Elbow's model, the audience is essential to help in revision, but the best words come from deep down inside, from one's voice. Problems are solved in this model by changing the inside; change in the outside, that is, power over others, follows from this success in dealing with oneself. No wonder Elbow ends with a chapter on "Writing and Magic"; magic is the only possible source for such ineffable energies. This relentlessly internal approach to writing is both the book's strength and its weakness. Writing With Power consists almost entirely of vivid, often visceral, usually organic metaphors for creation. ${ }^{12}$ These metaphors may help us see our processes of writing in new ways, but they also prevent any analysis of the social conditions of our writing. There is no real place in this model for a discourse group that gives one the structures of words one takes for granted.

Elbow has been a powerful writer for reform. Does his insistence that personal authenticity is the source of power apply to his own writing? He refers often to his own internal struggles in writing the book. I would argue, though, that its rhetorical power comes not from these struggles, but from its place in a group of texts. It gives a new metaphorical guise to familiar progressive education concepts, and makes an appeal to individualism that is a commonplace of American rhetoric. It has some affinities with a long line of straight-talking guides to self-

12. Those who favor such visceral metaphors should see Lester Faigley's paper, "Peristalsis as Paradigm: From Process to Product.’' 
improvement. Take, for example, the tone of hip moralism that combines with the traditional moralism of delayed reward in this passage: "If you slip into freewriting for the sake of producing good pieces of writing, then you put a kind of short-run utilitarian pressure on the process, and hinder yourself from getting all the other benefits" (Writing With Power 17). Now there is nothing wrong with using the jargon of self-improvement, any more than there is with using Marxist jargon as I do. My point is that both Elbow and I write within discourses developed in social processes, and that his account ignores these processes.

The work of Kenneth Bruffee can help us critique the appeal to reality that Leonard and Elbow make, especially in the recent essays in which Bruffee attempts to establish the theoretical grounds of collaborative learning. But his appeal to consensus is similar to theirs, and I think a lack of analysis of this consensus is the weak point of his theory. We might not see, at first, how different he is from Leonard and Elbow; he says in his textbook $A$ Short Course in Writing that he starts with a search for a method of writing that will be real. "Peer criticism," he says, "is the most real writing students will ever do as students," because the writer has an immediate and actual audience and purpose (115). Similarly, an exercise on reminiscence tells the student, "Just begin at the beginning and tell the whole truth" (3). Where Bruffee differs from Leonard and Elbow begins to be apparent in the next exercise, when he asks the student to retell a "family story" that has become formalized with retelling over time. This exercise suggests, as the personal reminiscence assignment in most textbooks cannot, the degree to which language is given by the social group, in this case the family. The student must try to translate the private language of the family into the language of the classroom, noticing the difference.

For Bruffee, "writing is a communal activity," not just an essence of meaning given by the individual to the community. Instead of tracing language to an original voice inside, Bruffee asks questions to make the reader "see an essay as a 'thing' someone has made, like a table or a chair-something artificially designed, shaped, and put together to serve a purpose" (122). He says his system of peer criticism will enable students to "gain a stronger sense of the degree to which knowledge, like writing itself, is a social phenomenon, and the degree to which the social context in which we learn permeates what we know and how we know it" (116). In his view of knowledge, the group is there from the beginning, defining the terms of thought, and does not simply come in at the end, as an audience.

But while Bruffee shows that reality can be seen as a social construct, he does not give us any way to criticize this construct. Having discovered the role of consensus in the production of knowledge, he takes this consensus as something that just is, rather than a something that might be good or bad. For instance, in his recent essays, he argues for collaborative learning because it is the norm in business, industry, and the professions. This is true enough, but I question whether analogy to these institutions is, in itself, an argument for a teaching method. We need to look at the consensus within these institutions as the result of conflicts, not as a monolith. To decide whether the groups in our classes are introducing students to new communities of discourse, or are confining them in 
ideological structures, we need a clearer definition than he gives of what these interpretive communities are, and a sense of the historical processes shaping them.

Bruffee defines discourse communities in terms of certain kinds of academic or non-academic knowledge. For instance, he says, "Every student is already a member of several knowledge communities, from canoeing to computers, baseball to ballet" ("Collaborative Learning"' 644). Bruffee suggests in another article that social differences are incidental to the process of education and should drop away if the students share an educational goal. "Outside the learning group . . . people may have widely different positions in the management hierarchy of a union or corporation, in the professional or student hierarchy of an educational institution, or in a system of economic or social class. But as collaborative learners all these people are peers. With regard to a course in ethnography or elementary Chinese, the vice-president of a corporation, the janitor, the English professor, the freshman, the society matron, and the shoe salesman must leave their social differences behind" ("CLTV' 38). ${ }^{13}$

This is an attractive and idealistic vision, but it assumes that knowledge is outside the realm of these people's social differences. Look over the list and ask who is most likely to be in a course on ethnography or elementary Chinese? Who, on the other hand, is likely to be in a course on English as a second language or on basic office skills? Who is likely to be in a basic writing course at the City University? To ask such questions is to realize that knowledge is not uniformly distributed in our society, and that it is not all of a piece. If we turn a blind eye to social factors we are likely merely to perpetuate the provision of different kinds of knowledge for the rich and the poor.

Bruffee sometimes includes non-academic knowledge in examples of discourse communities. For instance, he talks in one article about the contribution to the writing group of knowledge gained in office work, or in organizing a household. But what if one considers the knowledge of communities whose interests might be opposed, say the knowledge of social workers and the knowledge of welfare clients, or the knowledge of an accountant and the knowledge of employees in a factory to be closed? Such bodies of knowledge cannot be resolved into a consensus without one side losing something.

How are discourse communities made? Bruffee sees how society furthers thought or hinders it, but he does not see social and economic factors as providing his structures. For him, these factors are unfortunate limitations to our thought and conversation that must be eliminated as much as possible.

Limitations that may be imposed for example, by ethnocentrism, inexperience, personal anxiety, economic interests, and paradigmatic inflexibility can constrain my thinking just as they can constrain conversation. If my talk is narrow, superficial, biased, and confined to clichés, my thinking is likely to be so too. ("Collaborative Learning" 639)

13. See also two other essays by Bruffee, "The Structure of Knowledge and the Future of Liberal Education," and "Liberal Education and the Social Justification of Belief.", 
I would see such limitations as giving the structure to our thought. Ethnocentrism and economic interests are not just unfortunate habits, they are whole systems of ideas that people take for granted and use to make sense of the world. One cannot escape from one's economic interests and ethnic background, but one can try to understand how they shape one's thinking and social actions.

The model Bruffee gives for change in knowledge, adapted from Thomas Kuhn and Richard Rorty, leads us away from such analysis. It attributes the growth of knowledge and change of paradigms to factors internal to the discipline, such as the multiplication of anomalies and the shift of paradigms. The only conflict is between normal science and extraordinary science, or normal discourse and abnormal discourse. An alternative model would be in the work of historians and sociologists of science who see change in terms of social and economic factors. ${ }^{14}$ For instance, Bruffee might call his own composition theory a new paradigm, resulting from the new models of Kuhn and Rorty. I might call it an attempt to rationalize theoretically the methods he earlier developed, and I would trace these methods to the institutional need, which he describes in his article, to deal with new kinds of university students. Similarly, I might trace my interest in these questions to my teaching of basic writing at Queens College. Ultimately, I would trace both his thinking and mine to the challenges of Open Admissions at CUNY. And Open Admissions was not the result of a paradigm shift in the philosophy of education; it emerged from the political conflicts of New York City in the 1960s.

Bruffee's recent essay points out that "The view that knowledge is a social artifact . . . requires a reexamination of our premises as students of English and as teachers" ("Collaborative Learning" 650). His suggestions for reform are excellent: he would "demystify" the humanities and the relation of teacher to student by putting them in a social context. But I think he underestimates the difficulty of the reforms he proposes, because he sees the resistance to them as a matter of habit, not of ideology. In A Short Course, he describes the problem he is addressing in terms of what he sees as "a conflict between two forces: the docility and dependence created in young people by American schooling and the increasing demand of modern life that human beings be autonomous, flexible, and self-possessed" (vii). But these two forces are not in conflict if we see the interests of employers, rather than "modern life" as the force that makes demands here. Students can be both docile and convinced of their autonomy, freedom of choice, and control of their lives. A school that reproduced this ideological construct would be a successful school.

In his recent article, Bruffee sees some of these dangers clearly enough. He points out the "provincial" nature of what he and Rorty call normal discourse. $\mathrm{He}$ also seems to recognize the kinds of possible dangers in the use of collaborative learning that I pointed out in some of Leonard's examples. He refers to the need to avoid "the many possible negative effects of peer group influence: conformity, anti-intellectualism, intimidation, and leveling-down of quality." $\mathrm{He}$

14. A good introduction to the sociology of scientific knowledge is another Open University reader, edited by Barry Barnes and David Edge. 
would do this by making "collaboration . . . a genuine part of students' educational development" (652). I would do it by emphasizing conflict as well as collaboration. I think he is referring to the same sense of a divided role I have described when he says "we must perform as conservators and agents of change, as custodians of prevailing community values and as agents of social transition and reacculturation" (650).

\section{Lessons for Reformers}

I find I have no suggestions for assignments that are as innovative as those of the authors I am criticizing. But that is partly because what I have to suggest is not a method but a stance towards one's teaching. This stance requires a sort of doubleness: an awareness that one's course is part of an ideological structure that keeps people from thinking about their situation, but also a belief that one can resist this structure and help students to criticize it.

The sense of conflict in these three writers is clear enough when they describe their work as teachers. In each case they have a problem with existing institutions; in each case they offer an escape that I don't think works. Leonard, for instance, offers professionalism as an escape from the sense of pointlessness many teachers have: "It becomes clear how different a subject it is coming to be from the sodden, idealless drudgery of themes swoopingly red-inked and at the nearest possible moment thrown into the wastebasket" (193). Escape for him is through attention to the new research in composition in the 1920s ("Research on the Teaching of English"). But research will not change the basic antagonism of student and teacher he describes here.

Elbow, in his advice to students about writing in school, presents powerfully the role and limitations of the teacher:

Teachers are good for giving criticism because they read papers in piles of 25 or 50 . Take that criticism and use it. They are good at making you write when you don't feel like it, simply because they have authority. Instead of resenting this, try appreciating it and internalizing from it what may be the most important skill of all: the ability to write when you are in the wrong mood. They are not good at telling you what your writing feels like to a real human being, at taking your words seriously as messages directed to them, at praising you, or perhaps even at noticing you. Get these things elsewhere. (Writing With Power 234)

This is excellent advice, but Elbow's solution, that of using the tension between teacher and student, is based on his assumption that there is a world elsewhere of "real human beings." There is, of course, a world outside of school, and he is right to remind us of these other readers and writers. But the kinds of authority embodied in the school are present in the rest of the culture as well. The writer of an engineering proposal, a magazine article, or even a poem, is constrained by structures as powerful as those determining the freshman composition theme. The classroom alienation he takes for granted, in which the teacher processes 
batches of student raw material, is characteristic, not only of school, but of other institutions in our society.

Bruffee traces his own interest in collaborative learning to a similar realization of how alienating his work had become:

When I began teaching composition, I was still in graduate school. I had large classes, and I did not really know what I was doing. Every class hour seemed to stretch on to eternity. Grading papers took hours and was a dreadful grind. I kept hoping my classes would get smaller and the hour shorter. Instead, my classes got larger and the hour longer. I kept hoping I would learn to grade papers more easily and quickly. That did not happen either. Worst of all, I was not really sure that I was teaching anybody anything. (Short Course 184)

All three writers start by considering the drudgery of the work, the enormous numbers of papers, and the opposition of teachers and students. They want a change in the conditions of work, and a system that allows them to teach as well as just evaluate. They make a good case in these passages, whether they realize it or not, that our problems will not be solved just by new methods, or new theories, or new knowledge. We should begin by realizing that our interests are not the same as those of the institutions that employ us, and that the improvement of our work will involve social changes. No amount of merely educational reform will end the alienation described in these passages.

But this is not to say that all attempts at change are foiled by an all-powerful system, and that real change must wait until a revolution. Paul Willis warns other Marxist theorists against such an attitude at the end of Learning to Labour, his fine book on ideological reproduction in a British secondary school. $\mathrm{He}$ suggests the sort of double role for teachers that I have been arguing for here.

If we have nothing to say about what to do on Monday morning then everything is yielded to a purist structuralist Marxist tautology: nothing can be done until the basic structures of society are changed but the structures prevent us from making any changes. There is no contradiction in asking practitioners to work on two levels simultaneously-to face immediate problems in doing 'the best' (so far as they can see it) for their clients whilst appreciating all the time that these very actions may help to produce the structures within which the problems arise. (186)

What this approach means for, say, a basic writing teacher is that one teaches the forms of academic writing, so that students who might not finish four years of college have a better chance of finishing, without assuming that there is anything liberating about these forms or about academic discourse. One teaches job letters to the business communications students who need to get jobs downtown, without teaching that a job downtown is the answer to their problems. I have no specific new ideas for what we should do Monday morning, but I follow with interest those of other radical teachers. In this article, I am asking, not for a new kind of assignment, but for more skepticism about what assignments do to reproduce the structures of our society. 
We should keep a similar skepticism about the appeals to reality and consensus in composition theory and research. There have been a number of recent articles calling for a view of writing as a social process. ${ }^{15}$ This is a welcome corrective to the individualism of the cognitive psychology models of the 1970s. But we should not let our enthusiasm for this social view lead us to accepting social construction of knowledge as something good in itself. The kind of critique begun in College English by Richard Ohmann, Stanley Aronowitz, and others is even more appropriate now that we are seeing writing in a social context. I think these theories will be developed with more sophistication if we draw on critiques developed by such sociologists of education as Apple and Giroux, and on materials provided by historians of education. ${ }^{16}$

Leonard in the 1920s, and Elbow and Bruffee today, have made teachers aware of the need for changes in the way we teach. The work of sociologists and historians of education would help us to remain aware that the changes we propose may finally support an existing consensus and a conception of reality that supports those now in power. Our sense that something is wrong should lead us to criticize our own function in society, as well as our pedagogy. Otherwise, to use a comment of Leonard's from another, entirely different context, "It has less effect than a spoonful of water poured over a flock of ducks", ("Composition and Grammar" 448).

\section{Works Cited}

Apple, Michael, ed. Cultural and Economic Reproduction in Education. London: Routledge, 1982.

Applebee, Arthur. Tradition and Reform in the Teaching of English. Urbana: NCTE, 1974.

Aronowitz, Stanley. "Mass Culture and the Eclipse of Reason: The Pedagogical Implications." College English 38 (1977): 768-72.

Barnes, Barry, and David Edge, eds. Science in Context. Milton Keynes: Open UP, 1982.

Bazerman, Charles. The Informed Writer. 2nd ed. Boston: Houghton, 1985. . "Scientific Writing as a Social Act." New Essays in Scientific and Technical Communication. Ed. Carolyn Miller, et al. Farmingdale, New York: Baywood, 1983. 157-84.

Berlin, James. Writing Instruction in Nineteenth-Century American Colleges. Carbondale: Southern Illinois UP Press, 1984.

15. See, for example, the very different approaches of Patricia Bizzell, of Bruffee ("Writing and Reading as Collaborative Social Acts'), and of Charles Bazerman ("Scientific Writing as a Social Act"). Bazerman, like Bruffee, has a textbook based on his approach (The Informed Writer).

16. For example, one way of seeing how deeply ingrained and uncritical are the psychological categories we use to define basic writers is to read the historical treatment of these categories in Steven Shapin and Barry Barnes, "Head and Hand: Rhetorical Resources in British Pedagogical Writing 1770-1850.", 
Bizzell, Patricia. "Cognition, Convention, and Certainty: What We Need to Know About Writing." Pre/Text 3 (1982): 213-43.

Bruffee, Kenneth. "CLTV: Collaborative Learning Television." Educational Communication and Technology Journal 30 (1982): 26-40.

. "Collaborative Learning and the 'Conversation of Mankind.," College English 46 (1984): 635-52.

. "Liberal Education and the Social Justification of Belief.' Liberal Education 68 (1982): 95-114.

A Short Course in Writing. 2nd ed. Boston: Winthrop, 1980.

. "The Structure of Knowledge and the Future of Liberal Education." Liberal Education 67 (1981): 177-86.

- "Writing and Reading as Collaborative Social Acts." The Writer's Mind. Ed. Janice Hays.Urbana: NCTE, 1983.

Centre for Contemporary Cultural Studies. On Ideology. London: Hutchinson University Library, 1978.

Connors, Robert. "The Rise and Fall of the Modes of Discourse." College Composition and Communication 32 (1981): 444-55.

Cremin, Lawrence. The Transformation of the School. New York: Vintage, 1961.

Curti, Merle. The Social Ideas of American Educators. New York: Scribner's, 1935.

Dale, Roger, et al., eds. Schooling and Capitalism: A Sociological Reader. London: Routledge, 1976.

Dewey, John. The School and Society. Chicago: U of Chicago P, 1898.

Douglas, Wallace. "Why Know Our History." English Journal 68 (1979): 16-21.

Elbow, Peter. Writing With Power. New York: Oxford UP, 1982.

Writing Without Teachers. New York: Oxford UP, 1973.

Faigley, Lester. "Peristalsis as Paradigm: From Process to Product."' Paper presented at the panel on "Nutrastylistics" at the Conference on College Composition and Communication, Minneapolis, March 1985.

Giroux, Henry. Theory and Resistance in Education: A Pedagogy for the Opposition. London: Heinemann Educational Books, 1983.

Halloran, Michael. "Rhetoric in the American College Curriculum: The Decline of Public Discourse." Pre/Text 3 (1982): 245-269.

Hook, J. N. A Long Way Together. Urbana: NCTE, 1979.

Kantor, Kevin. "Creative Expression in the English Curriculum: An Historical Perspective." Research in the Teaching of English 9 (1975): 5-29. 
Leonard, Sterling. "As to the Forms of Discourse." English Journal 3 (1914): 201-211.

. "Composition and Grammar in the Junior High School."' The Classroom Teacher 10 (1927): 309-449.

. ' 'Current Definition of Levels in English Usage.' English Journal 16 (1926): 345-59.

- The Doctrine of Correctness in English Usage, 1700-1800. Madison: U of Wisconsin P, 1929.

- English Composition as a Social Problem. Boston: Houghton, 1917.

. “How English Teachers Correct Papers." English Journal 20 (1923): 517-31.

. "Relating the Teaching of English to Reality." Nation's Schools 4 (1929): 45-48.

" "Research on the Teaching of English." Journal of Educational Research 19 (1929): 317-21.

. 'What About Correct English?', The Teachers Journal and Abstract 6 (1931): 252-56.

Leonard, W. E. 'Sterling Andrus Leonard.' Dictionary of American Biography. 9: 168-9.

Marckwardt, Albert. Facts About Current English Usage. New York: AppletonCentury, 1938.

Ohmann, Richard. English in America: A Radical View of the Profession. New York: Oxford UP, 1976.

_- "Use Specific, Definite, Concrete Language.' College English 41 (1979): 379-89.

Ravitch, Diane. The Great School Wars: New York City, 1805-1973. New York: Basic, 1974.

Richards, I. A. Practical Criticism. New York: Harcourt, 1929.

Shapin, Steven, and Barry Barnes. "Head and Hand: Rhetorical Resources in British Pedagogical Writing 1770-1850.' Oxford Review of Education 2 (1976): 235-50.

Sommers, Nancy. "Responding to Student Writing." College Composition and Communication 32 (1982): 148-56.

Tate, Gary, and Edward P. J. Corbett, eds. The Writing Teacher's Sourcebook. New York: Oxford, 1981.

Williams, Raymond. Keywords. London: Oxford UP, 1976.

Willis, Paul. Learning to Labour: How Working Class Kids Get Working Class Jobs. Farnborough, England: Saxon, 1977.

Wright, Evelyn. "School English and Public Policy."' College English 42 (1980): 327-42. 


\section{College English}

\section{Acknowledgements}

An earlier version of this paper was delivered as a talk at the Georgetown University Writing Center; my thanks to Dan Moshenberg and James Slevin for their invitation and their helpful comments. Thanks also to Judy Fishman, Mary Dobbie, Cyril Knoblauch, Lester Faigley, Mara Holt, Andrew Cooper, Ann Judd, Maxine Hairston, Edward Smith, Michael King, Roger Cherry, and Tess Cosslett, and a number of anonymous referees who read and commented on one draft or another. Kenneth Bruffee's responses to an earlier version were helpful in revision. None of these readers necessarily agrees with anything I say here. 